\title{
The Phenomenal Growth of Pentecostalism in the Contemporary Nigerian Society: A Challenge to Mainline Churches
}

\author{
Benjamin C.D. Diara, Ph.D. \\ Department of Religion, University of Nigeria, Nsukka \\ E-mail: nsubend@yahoo.com \\ Nkechinyere G. Onah, Ph.D \\ Department of Religion and Cultural Studies \\ University of Nigeria, Nsukka \\ E-mail:nkglo06@yahoo.com
}

\section{Doi:10.5901/mjss.2014.v5n6p395}

\section{Abstract}

The bid to survive the landslide progress being made by the Pentecostal churches at the expense of the membership of the mainline churches in Nigeria has left most mainline churches with seemingly no alternative but to imitate those factors that enhance the phenomenal growth of the Pentecostal churches. At the end of the day, it is termed influence of Pentecostalism on mainline churches. On the other hand, a few members of the mainline churches have a critical attitude to the influence of Pentecostalism in mainline churches and hence rather tend to condemn everything Pentecostal. To the present researchers, the solution to the problem does not reside in either condemning Pentecostalism in to to or in imitating Pentecostal tendencies blindly, but in discovering through a comparative study what those things are that give the Pentecostal churches an edge over the mainline churches in matters of church growth, and in endeavouring to supply those missing essentials in their own folds. This study therefore is aimed at discovering such missing essentials of church life in the mainline churches through an analytical study of the factors that enhance the growth of Pentecostal churches. The methodology adopted in the study is both historical and sociological. While some of the Pentecostal factors may be apparently negative and unbiblical the mainline churches should appreciate the positive ones and make use of them for their own revival hence the church is a theatre of the Holy Spirit. Thus, charismatic activities are not the exclusive reserve of particular ecclesiastical movements.

\section{Introduction}

Over the years, the terminology used to describe Pentecostal churches has been varied and diverse owing to the various views which people have about Pentecostal movement from its inception. Among the first terms used were schismatic movements, break-away groups, separatist churches, etc. With passing on of time and better understanding, people's opinions about Pentecostalism began to change and there came such more positive terms for Pentecostal churches as prophetic, healing, spiritual and finally Pentecostal. Hence Pentecostal churches are variously known today as prophetic, healing, spiritual or Pentecostal movements.

Most of the early terminology were used to denote the fact that the Pentecostal churches are in most cases the outcome of a separation of groups of members from the orthodox or mainline churches such as the Roman Catholic, Anglican, Presbyterian, Methodist and Baptist churches, hence one of the most widely used of all the terms is separatist churches. According to Parrinder in Uzoho (2000:21) these are "sects which have split away from or sprung up in relative independence of the older mission churches"

Pentecostal churches spring up mostly in areas where the Christian religion has been in existence before. "Protestant" denominations have tended to contribute more towards the promotion of Pentecostal churches than the Roman Catholic denomination. Perhaps this is so because the "Protestant" churches are freer both in their teaching and practices, and most especially through the translation of the scriptures into the vernacular languages.

In March, 1967, after the outpouring of the Holy Spirit on a Roman Catholic congregation at Notre Dame and his manifestation in glossolalia, an old missionary asked some of those involved: "Now that you have received the Holy Spirit, when do you plan to leave the Catholic Church?" (O' connor: 1968). Those questioned were amazed at his question since the only important effect of their experience was that they felt themselves "better Catholics". O' connor uncompromisingly identified the adverse effect of Pentecostalism on Protestant churches when he said, 
In the Protestant world, the Pentecostal movement has often led people to separate from their parent churches and founded new ones. The Catholic Pentecostal movement has manifested no such tendencies. On the contrary, it has greatly deepened the attachment of its members to the church. p.84

The Pentecostal/charismatic groups of the Roman Catholic Church, unlike their counterparts in the Protestant churches, recognize the priests of their churches at their meetings as an antidote to doing anything which would be incompatible with the teaching or practice of the church. They do not regard their prayer meetings as a substitute for the church's liturgy. Their leaders are also active and enthusiastic promoters of their churches hence the Roman Catholic Church does not contribute much to the proliferation of independent Pentecostal movement.

Like many other incidents in history, some people rashly concluded that Pentecostal movement is merely ephemeral. But such opinions seem to have been misconceived because Pentecostal churches have persisted and continued to increase in number and size. Achunike (2004:19) corroborates this point in these words: "Indeed the growth of Pentecostalism has assumed a phenomenal proportion. But this growth is not based on its doctrine because doctrinally Pentecostalism is not a consistent whole". This suggests that the reasons behind the phenomenal growth of Pentecostalism in the contemporary Nigerian society should be sought for outside doctrinal domain. For in many respects Pentecostal churches fall short of the biblical principles and practices of church growth. Nevertheless, many of them have a good grasp of the Christian faith and in fact appear more serious with the faith than the mainline churches.

\section{Proliferation of Pentecostal Churches in Nigeria}

The beginning of proliferation of Pentecostal churches in Nigeria could be traced to the period after the Nigerian independence. The political independence of Nigeria seemed to have in turn encouraged religious independence in the country, giving rise to a situation whereby the strong tie of membership of the mainline churches was loosened. The Anglican Church and her other sister Protestant churches were the major victims of this development because of their loose attitude to Bible reading as opposed to the Roman Catholic Church which restricted Bible reading to the priests. Consequently, Christians in Protestant churches began to see themselves more as individual Christians than as part of the corporate body, the church.

Following this development, there sprang up independent Christian groups with evangelical and Pentecostal persuasions, most of which initially claimed to be non-denominational or inter-denominational, only to turn round and become churches later. Most of the Pentecostal and African Independent churches existing here and there in Igboland such as Christ Apostolic Church, Holy Church of Christ, Christ Chosen Church, Christ Apostolic Faith, Christ Healing Church, Christ True Mission, Church of God Mission, Apostolic Faith Ministry (Abosso) to mention but a few, took their origin from this period.

Thousands of Pentecostal churches have sprung up in Nigeria since 1970. The Newswatch Magazine (December 3, 2001: 26 - 30) identified 1018 Pentecostal churches among others in Nigeria. Kalu (n.p: 4) made a typology of such Pentecostal groups, thus (1) Interdenominational Fellowships (2) Evangelistic Ministries, e.g. Deeper Life Bible Church, (3) Deliverance Ministries, specializing in exorcism (4) Prosperity or Faith Ministries e.g. Zoë Ministry, Idahosa's Church of God Mission (5) Intercessors for Africa; (6)Missionary and Rural Evangelism, e.g. The Christian Evangelical Social Movement, Christian Movement Foundation (Rural Evangelism Outreach (REO) Ministry belongs to this group); (7) Bible Distribution Ministries, e.g. Gideon Bible International whose members must be born again and must be active in their churches; (8) Classical Pentecostals such as Assemblies of God Mission, Four Square Gospel, etc. (9) Children Evangelism Ministries whose branches have mushroomed nationwide from late 1980s. The demarcating lines between the Pentecostal groups are between fellowships and churches and between holiness and prosperity groups.

The fast proliferating independent churches, which are mostly of the new wave or firebrand Pentecostal type, began to gain ground across the country in 1986 with the founding of Benson Idahosa's Church of God Mission. Their catchments areas appear to be the cities and urban areas where there is more concentration of the rich and upwardly mobile youths. In such cities as Lagos, Abuja, Enugu, Port Harcourt, Aba, Onitsha, Owerri, Ibadan, Warri, Benin, etc., the churches are rising up in shops, stores, disused buildings and warehouses, on daily basis. For ministers of such churches, Christians are not meant to suffer, and they should not be poor, hence "poverty is a curse". No wonder their type of Christianity rarely exists in rural areas.

Such churches have turned warehouses into delightful places of worship. In Lagos and other big cities, it is only the big-time churches that afford to buy warehouses and convert them to places of worship. The Mike Okonkwo's Redeemed Evangelical Mission (TREM) at Obanikoro, Tunde Barare's Latter Rain Assembly at Akilo road, Ogba; Chris Okotie's Household of God Church at Oregun, Chris Oyakhilome's Christ Embasssy at Oregun and Joseph Agboli's victorious Army at Acme Road, Ogba, are some such big-time Pentecostal churches in Lagos (Ekenna: 2001: 20). 
The smaller or upcoming churches make do with rented apartments and shops. It is not unusual to see two-storey building of six flats that has four churches operating in it. In this way, most of the streets in our big towns have been turned into "church streets". Good examples of such streets are found at Agbani Road in Enugu. On the stretch of the road from Nise bus-stop to Gariki motor part, a distance of about one and half kilometers are over 30 churches operating in the different buildings along the road alone. Some of the buildings, mainly two or three storey, have about four or five churches in them. A particular storey building with six flats at Ebony Paints bus-stop has four of the flats rented and converted to places of worship by different churches.

Another good example is Omotoye Estate, Agege Lagos. There are about eight different churches on the Street in addition to the twin duplex occupied by two different churches. A Sunday morning along such streets only reveals a cacophony of sounds coming from drumming, singing or preaching from the churches. The pastors shout on top of their voices even with their microphones and loudspeakers. This presents the picture of a country over-crowded with churches; myriad of Pentecostal and Independent churches jostling for position and space, yet crime and immorality rate is increasing daily.

Commercial "prayer warrior" and "preachers" also abound. Travelers on the Lagos-Abuja or Lagos-East routes are not unfamiliar with "prayer warriors" who pray for passengers for God's protection against accidents, armed robbers and other evil-forces along the road. At the end, the passengers are required to donate some money in support of the ministries. The mobile preachers, as they are called only preach to and pray for travelers. Often, they give non-existing addresses and fake names of their churches so that those who may have cause to look for them will not be able to find them. With this type of attitude one becomes sure that much of the bus preaching and praying business is all about duping and " 419 ".

In Newswatch Magazine, Obiora (Dec. 2001: 25), a Reverend Father, gave a vivid narration of unconventional things that happen in the Pentecostal churches. He described some of the Overseers, Presidents and Founders of Pentecostal churches as businessmen who inject the name of Jesus Christ into their trade to defraud the gullible and the ignorant. He says that members of such churches are cajoled into "paying tithes, making donations, presenting gifts and levies to their spiritual leaders. He concluded by saying that "New Wave Preachers are the new evidence of the changing face of Christianity in Nigeria. Diara (2009) describes the situation as aberration of Christian tradition.

In the same vein, Alghalus (Dec. 2001: 20) President of God's Kingdom Society in Newswatch Magazine was of the opinion that the proliferation of churches was the devil's handiwork. He maintains that proliferation of churches does not truly translate to the "expansion of the body of Christ", but a machination of the devil to deplete the church of God. He described most Pentecostal pastors as "Charlatans' whose main pre-occupation is to deceive gullible individuals, especially the youths by advertising miracles and prosperity.

The issue of prosperity preaching and miracles for which the mainline churches are worried has indeed become the linchpin of the flourishing Pentecostal churches. Spiritually and doctrinally sound Pentecostal churches such as the Deeper Life Bible Ministries founded by William Kumuyi, which do not lay emphasis on prosperity and miracles, but on "saving of souls" are no longer enjoying much popularity. The churches that command great fellowships nowadays are those that dwell so much on prosperity and miracles.

Chris Oyakhilome's Christ's Embassy, Ayo Oritsejafor's Word of Life Bible Mission, Lawrence Osagie's Power line Chapel, David Oyedepo's Winner's Chapel and Enoch Adeboye's Redeemed Christian Church of God are in the forefront of prosperity preaching. Others include Pastor Ezekiel's Christian Pentecostal Mission, Agboli's Victorious Army and Christ Okotie's Household of God Church, to mention but a few. Their watchword in their churches, crusades, radio, television, newspapers and magazines, is "financial breakthrough".

In many of such churches, the poor are made to feel inferior during offerings and fundraising activities. It is emphasized that members should pay their tithes regularly so as to obtain financial breakthrough. Steady payment of tithes is a prerequisite for achieving prosperity, and the tithes end up in the pockets of the "men of God". A definite amount of money is fixed as the minimum for service offering and anyone who gives less is not qualified to occupy a seat in the church.

Oyakhilome, Adefarasin and Okotie run what is popularly known as "Funky churches". Their congregations largely consist of young men and women and professionals. Dressing in these churches is according to the disposition of the members. Nothing is barred or forbidden in matters of dressing. Young girls wear skimpy and short skirts and sleeveless tops that expose their nakedness more than they can cover. Women come to church in trousers and without head ties or scarves. 


\section{Factors of Pentecostal Church Growth}

The causes of rapid growth and advancement of Pentecostal churches in Nigeria are diverse and varied ranging from leadership ambition to numerous other factors such as pursuit of material prosperity, good pastoral care, freedom in matters of liturgy and dress style, and emphasis on the activities of the Holy Spirit namely, divine healing, miracles and gifts of the Holy Spirit, etc. The present researchers have classified these causes into four: political, economic, social and spiritual factors.

\subsection{Political factor}

Leadership ambition is one of the brains behind proliferation of churches in the Nigerian society. Many find opportunities for leadership in the new (Pentecostal) churches. Cases abound of individuals who were baptized in mainline churches but later left the churches and joined other churches from where they joined yet others until they got to where they were given leadership positions. Many break away from their churches for the ulterior motive of becoming leaders of their own churches. Pentecostal leadership exists under different designations such as President, General Overseer, Apostle, Apostle General, Bishop, Archbishop, Prophet, Healer, etc.

The system of Pentecostal church government is also fascinating. It is so simple and as such decisions are not politicized as in Orthodox churches. Many are apparently disgusted with the type of politics that goes on in the mainline churches and this directly or indirectly contributes to loss of membership in such churches.

\subsection{Economic factor}

The pursuit of material prosperity appears to be the greatest factor that contributes to the promotion of Pentecostalism today, especially in Nigeria. Many who throng to Pentecostal churches are people looking for prosperity, and being conscious of this fact, many of their ministers have turned prosperity preachers. Many leave the mainline churches with the single motive to form their own churches where they will not only be chief executives but also financial controllers, and most of such people choose the Pentecostal mode of church life for easy attraction of the masses.

The messages of prosperity and the get-rich-quick syndrome in Nigeria today are products of bad economy. Pentecostal pastors capitalize on this situation to exploit the masses and to hold them spell-bound in their fold. When South Africa was under apartheid, churches there preached only messages of freedom, because that was what the people wanted to hear. Today, in Nigeria, Pentecostal pastors adopt similar strategies that are simply meant to retain old members and attract new ones. What matters is no longer what pleases God but what pleases the members and is capable of attracting many others to the fold.

\subsection{Social factor}

Social welfare of members in form of pastoral care is another factor that contributes to the flourishing of Pentecostal churches. Pentecostal pastors are indeed exceptionally good in pastoral care. The moment a convert enters their churches, he is handed over to a team of follow-up specialists who give personal attention and care to new converts. Within a short while, the new convert feels totally reassured as his past, present and future experiences are revealed by the man or woman of God. He is told what to do for the betterment of his social condition.

There is however some amount of pastoral care in the mainline (mission) churches but it is not as intense and as thorough as that in the Pentecostal churches where attention is given even to the small baby in the mother's arm and fetus in the womb. The better care in Pentecostal churches is also seen in the readiness of the prophets/pastors to spend a lot of time with each sick person. Most of the Pentecostal churches have a particular member called worker, evangelist or elder whose duty it is to visit and admonish new members of the church. He is usually a visioner and is charged with the responsibility of pastoral care to members.

On the other hand, young people are attracted to some of the Pentecostal churches as a result of the freedom they allow in matters of dressing. In such churches, dressing is according to the disposition of the members. Nothing is forbidden in matters of dressing. Women and girls are free to come to church in the attires of their choice and without head ties or scarves. As it concerns the clergy, the Pentecostal churches also have a simple and free attitude to dressing. Most Pentecostal pastors choose to dress in such a way as to make communication and gesticulation during preaching easier. But there is no such freedom in orthodox churches. This makes some young people who have some sense of pastoral call or ambition to decide for Pentecostal churches. 
Pentecostal pastors encourage their members to dress to their taste claiming that it does not really matter how they appear, for God is not interested in one's outward appearance. They refer to the churches that insist on proper dressing as old fashioned churches that are still operating in the realm of the Old Testament. They believe that what one does with one's body does not matter as far as spirituality is concerned. What matters is the purity of the heart. They often quote Matthew 5:8 "Blessed are the pure in heart for they shall see God", to cover up their immoral tendencies. This type of teaching by the so-called men of God has brought general permissiveness in the churches and many, especially the youths are very happy with it.

\subsection{Marital Factor}

Another strong factor of Pentecostal church growth is chances of getting married easily especially on the side of women. No wonder it is mostly women and young people that throng to Pentecostal churches. Young men feel free to relate to ladies, and vice-versa, in the Pentecostal churches where they are encouraged to demonstrate love towards one another and to marry one another. Most Pentecostal churches have a well-planned marriage scheme which attracts young boys and girls to them. For the above reasons, people, especially the youth, who have lost interest in the rigidity and monotony of church life in mainline churches easily call it a quit from such churches and make their way to the Pentecostal churches.

\subsection{Spiritual factor}

The practice of spiritual gifts and emphasis on the activities of the Holy Spirit, especially divine healing is another strong factor that attracts people to the Pentecostal churches. People are generally impressed by the extraordinary things they see in such churches which are not present in the mission (orthodox) churches. Such things include prayer with speaking in tongues, healing and deliverance services, prophecy/vision, etc (Bonke, 2005). When visitors to such churches see these things, they soon become convinced that there is something in the new movement, and as such they are encouraged to stay on.

Other enhancing spiritual factors that attract people to Pentecostal churches include inspiring worship services, evangelical activities and Pentecostal doctrines (Graham, 2008). There is no doubt that worship services in most Pentecostal churches are not only entertaining but inspiring. The use of choruses for worship, which is prevalent in Pentecostal churches is often more inspiring and attractive to many than the use of hymns in mainline churches as everybody does not know how to sing hymns. The evangelical and Pentecostal doctrines of the Pentecostal churches also fascinate people more than the dogmatic traditions obtainable in most orthodox churches.

Of all Pentecostal factors of church growth, miracle working especially healing miracle, seems to be the strongest for which, people join the new movements, and it is in fact, one of the major sources for the successes of Pentecostal ministries in the contemporary society, especially in Nigeria. Though performing of miracles is only one aspect of the Pentecostal tradition, it is often the pivot of Pentecostal activity especially among the prophet healing types. And this attitude has marketed the Pentecostal churches tremendously in Nigeria.

\section{Pentecostalism in Mainline Churches}

The experiences and practices of Pentecostalism in orthodox (mainline) churches have been described as charismatism or neo-Pentecostalism. This according to O' connor (1972) implies the reappearance of the same Pentecostal features and experiences which are characteristic of Pentecostal churches within the more traditional Christian confessions; the Lutheran (1962), the Methodist (1960), the Presbyterian (1960), the Anglican (1960), and the Roman Catholic (1967).

According to a rigid Pentecostal dialectic, the churches in which Pentecostalism as a movement first appeared rejected it. Hence, the Church of England rejected Wesley's Methodism with its Pentecostal confession. Also, the Methodist church within which it had come into existence in turn rejected Pentecostalism, and it had to make its way outside its mother church. Hence one of the Evangelical groups in the church organized itself into a church, and therefore had its own institutions, a theology, a liturgy, schools and seminaries, while the other preserved a greater fidelity to the original experience and remained informal (Chatfield: 1998: 102). The former group eventually became the nursing mother of modern Pentecostalism.

What is described as modern Pentecostalism is a movement of Evangelical Christians in USA which began at the beginning of the $20^{\text {th }}$ century. In this formal sense of Pentecostalism as a movement, Pentecostal spirituality spread mainly by way of testimony and often among the poor and illiterate, especially women, whose experience they shared, 
especially in Latin America and Africa.

Originally, the Pentecostal movement was a form of liberation movement which is often suitable to the less privileged. The whole approach matched in many respects with the style of the Gospel (Good News) that is preached to the poor. Since the beginning of the $20^{\text {th }}$ Century, Pentecostalism had shown greater vitality than any other Christian movement. In Latin America, they make up the largest religious group after Catholicism. In Italy, two thirds of all Protestants are Pentecostals (Chatfield, 1998).

Poverty, sickness, oppression, etc., constitute significant factors of promotion of Pentecostalism. For instance, when South Africa was under apartheid, churches there preached more of messages of freedom because that was what the people wanted to hear. Also in Nigeria, the proliferation of Pentecostal churches in Nigeria is more or less a product of bad economy and bad health. Clever pastors capitalize on such situations to the advantage of their churches.

Modern Pentecostalism in form of charismatic movements was introduced into most mainline churches including the Roman Catholic Church in the 1960s and 70s. The movements began to have a major impact on the Anglican Church specifically in the 1960s, first in the United States of America (Chatfield: 1998: 102). There is now an International Anglican Organization known as "Sharing of Ministries Abroad" (SOMA) whose aim is to share charismatic insights, teaching and experiences throughout the Anglican world.

Scholars such as Kalu (1996: 247), Bolton (1992: 4-5) and others maintain that the rise of Pentecostal Movement in Igbo land should be seen against the backdrop of the aftermath of the Nigerian-Biafran War. As the people faced the situation of insecurity, sickness and poverty that resulted from the war, there was the tendency to search for solutions to the situation. It was soon discovered that spirituality could be a solution to virtually all problems of life, hence the proliferation of Pentecostal Movements which sprang out mostly from the orthodox churches. Coincidentally, this period also marked the advent of Scripture Union as a ministry in Igbo land.

Members of mainline churches, who happened to come in contact with members of the Pentecostal churches through their membership of the non-denominational or interdenominational fellowships and ministries such as the Scripture Union (S.U.), soon became influenced by their practices. In the bid to revive the prayer life, worship and preaching of their churches, and to disprove the then wide-spread notion that orthodox (mainline) churches were dead churches, the newly Pentecostal influenced members of the mainline churches gradually began to introduce the ecstatic practices of their fellowship and ministries into their churches.

Gradually, some of such mainline churches began to accept the new movement in order to remain relevant and in the spirit of the language of the time, while others vehemently opposed it. Through charismatic activities, both the membership and leadership of the mainline churches gradually became influenced by the wind of Pentecostalism. Before then however Pentecostalism has caused heated persecutions in many churches, which in turn promoted the cause of proliferation of Pentecostal churches.

\section{The Challenge before the Mainline Churches}

Mainline churches in Nigeria should not imitate the contemporary trend of Pentecostalism hook-line and sinker. If everything Pentecostalism is imbibed by the mainline churches, time shall come when all the churches will begin to allow ladies to attend church worship in improper dresses and without covering their hairs. And also, before long, the churches will turn funky and begin to practice such carnal new wave Pentecostal tendencies as rocky dance and "holy kiss" within their circles. Pastors of the mainline churches should therefore study the system of church life and growth among the Pentecostals analytically and critically and at the end of the day reject the negative and unbiblical factors and embrace and adopt the positive and biblical ones for their churches.

The practice in some churches, where a male polygamist during baptism has to choose his favourite wife out of the whole lot and the rest sent away under the stigma of forced divorce should be discarded. The Bible provides that churches should be a place of rehabilitation to the socially challenged and castaways. Such women who float to the Pentecostal churches will not have any reason to leave their churches if they find in their churches a religious haven which accepts them wholeheartedly and with sympathy, and give them respectable places among their fellows.

The mainline churches should have the socio-economic well being of their members high in their priority list. Many who throng to Pentecostal churches are people looking for how to overcome the sting of poverty. The consciousness of this fact on the part of the leadership of mainline churches will go a long way to influencing the messages and programmes of the churches and making them economically welfare-oriented thereby reducing, if not stopping entirely, the tendency for members to leaving their churches in search of where their welfare will be provided for.

Another Pentecostal factor that ministers of mainline churches should take seriously is good pastoral care. Indeed, Pentecostal pastors are exceptionally good in this aspect. The minister of the mainline churches should take a clue from 
the pastoral attitude of Pentecostal ministers in this regard. They should develop a strong pastoral care programme which should include raising a team of ushers and a visitation and a prayer team whose responsibility it is respectively to receive new members into the church and to visit and pray for members of the church, especially new converts and their families. By so doing members of the church are assured of the betterment of their conditions with hope of spiritual as well as social fulfillment at the end of the day.

The practice of and emphasis on the gifts of the Holy Spirit, especially divine healing, is another strong factor that ministers of mainline churches should adopt in their church systems (Bonke, 2007). People are generally captivated and spiritually motivated when they see extraordinary things such as speaking in tongues, healing and deliverance ministrations, prophecy/vision, etc in churches. When people see these things in their churches, they get convinced that something is happening in their churches, and as such they are encouraged to stay on but if the opposite is the case the tendency to leave for where things are happening is high.

In addition, leaders of mainline churches should include inspiring worship services, simple system of church government, evangelical and Pentecostal messages, youth programmes that provide for chances of getting married easily especially on the side of women, etc in their liturgical and organizational systems. Lively worship with inspiring praise and worship sessions, powerful messages and charismatic prayer ministrations are not the exclusive reserve of particular church denominations or movements called "Pentecostals". Actually, if all churches of today are true to the doctrines of the Bible, there should be no line of demarcation between those that are referred to as Pentecostal and those that are referred to as Orthodox churches hence, biblically speaking, the Christian church is both Orthodox and Pentecostal in tradition.

Unless Nigerian pastors uphold the true doctrines of the Bible and preach salvation and holiness messages in their churches and programmes, the situation of Christianity in Nigeria will degenerate beyond the present situation and the souls of many Nigerians including members of the church will be doomed for hell as "judgment will begin from the house of God".

Mike Okonkwo one of the leading Pentecostal pastors has seen the situation in this same light when he condemned the materialistic attitude of his fellow Pentecostal ministers on November 13, 2001. He warned Pentecostal pastors against laying so much emphasis on miracles and prosperity to the detriment of holiness and salvation. He decried a situation in which people now see the supposed house of God as places to come and make wealth. He accused Pentecostal pastors of relegating the teaching that "the just shall live by faith" to the background in the quest for prosperity, and called on them to preach the basics of the Bible to avoid the bane of the churches in America and Europe (Newswatch: Dec. 2001: 20). Christian churches in Nigeria, Pentecostal and Mainline alike, are therefore called upon to go back to the Bible doctrines and practices.

Considering the high level of abuse of biblical Pentecostalism in most Pentecostal churches in Nigeria today, one then wonders why the mainline churches should tend to blindly imitate Pentecostal churches. Nevertheless, as has been expressed earlier, there is this competition among churches in Nigeria whereby the mainline churches must struggle to remain relevant in the society.

The bid to prove their relevance and to flourish like the Pentecostal churches has thus moved many Mainline churches in Nigeria to enter into the contemporary church growth competition in the society. This contemporary ecclesiastical development has left many mainline churches with seemingly no alternative but to imitate those factors that enhance the flourishing growth of the Pentecostal churches without any conscious efforts to sieve the positive out of the negative. This unselective attitude is not encouraging.

The mainline churches should not lose their doctrinal and traditional identity by copying just anything that modern Pentecostals do. They should be selective in allowing influence of Pentecostalism in their fold. They should rather always surrender to the influence of the Holy Spirit and not to new wave Pentecostal practices.

\section{Conclusion}

The history of the church shows that at each period there was no disparity between "the organization" (the church) and the activities of the Holy Spirit. The Holy Spirit was and is still the soul and life of the church, so in all generations, the Holy Spirit has been the source of life and inspiration for the Church. The mainline churches should therefore not feel inferior to the Pentecostal churches in matters of the activities of the Holy Spirit.

Ironically, whenever the term "church" is mentioned, many think of the visible church; that religious institution which is there for all to see in its sociological complexity and cultural diversity. In most cases, people view the church under its sociological aspect as a tangible reality at the mercy of all other contingencies. This is why people tend to classify the church into Orthodox and Pentecostal churches today, and this is why many churches are today abusing biblical 
Pentecostalism in the bid to remain relevant to the needs of the society.

But in the actual sense, the church is a reality of an entirely different order. The church is at once visible and invisible. The church of God is made up of individuals and families, and is thus prone to all the hazards of human weakness. But it is also enlivened by the Holy Spirit, clothed with His Power and in possession of His pledge of fidelity.

In the Great Commission the apostles received as it were last instruction from their Master Jesus, an order not to launch out on their own initiative but to wait for the promise of the Father. The "structured" church is first and foremost not a court of jurisdiction but a sacramental reality. The Holy Spirit rests upon that which he commissioned. The ecclesiastical reality derives from the commission of the apostles by the Lord Jesus through the Holy Spirit which culminated in the event of the Pentecost.

We cannot therefore speak of two types of churches, one visible and institutional, and the other invisible and spiritual. The unity of these two dimensions is essential to the very concept of the church. As we view the church in faith, we cannot set one in contrast to the other, a "spiritual" church, which is wholly faithful to the Gospel and the Spirit, and an "institutional": church, which is more or less in the nature of an armed citadel. The church is the one Body of Christ; it is not divided.

On this note, it is pertinent to state that it is not all that proper to classify Christian churches into Pentecostal and non-Pentecostal churches, for the church is one. The word of God does not provide for such discrimination in matters of ecclesiastical identity, especially in terms of spirituality. The church is the theatre of the Holy Spirit irrespective of denominational differences. Therefore, every church should see in her very identity a Pentecostal tradition inherent from the apostolic experience of the Pentecost event.

\section{References}

Achunike, H.C. (2004) The Influence of Pentecostalism on Catholic Priests and Seminarians in Nigeria, Onitsha: Africana First Publishers Ltd.

Alghalus, O. (2001) "Proliferation of Churches in Nigeria" in Newswatch Magazine, Dec Issue.

Bolton, F.L. (1992) And We Beheld His Glory, Harlow: Christ King Pub. Co.

Bonke, H. (2007) Holy Spirit Revelation \& Revolution: Exploring Holy Spirit Dimensions, Orlando: E R Productions LLC. (2005) Evangelism By Fire, Orlando: Full Flame LLC.

Chatfield, A., (1978) Something In Common, Nottingham: St. John's Extension Studies

Diara, B.C. (2009), History and Doctrine of Evangelical Christianity, Enugu: Iman Publicity

Ekenna, G. (2001) "Has the Church in Nigeria Become a Lucrative Business Venture" in Newswatch Magazine, Dec.Issue.

Graham, B. (2008) The Holy Spirit (New Edition), Nashville: Billy Graham Evangelistic Association.

Kalu, O.U. (ed.), (1978) Christianity in West Africa: The Nigerian Story, Ibadan: Daystar Press.

Obiora, F.K (Dec. 2001) The Divine Deceit Business in Religion" in Newswatch Magazine.Dec. Issue.

O' Connor, D.E. (1968) The Pentecostal Movement, London: Oxford University Press.

- (1972) Pentecostalism and Charismatism, Notre Dame AVE Maria Press.

Uzoho, V.N., (2000) Women in African Independent Churches, Owerri: Concave Publishers. 